\title{
JULIUS CASSERIUS.
}

BY D. HUNT, JR,, M. D.

THE recent anniversary of the birth of Harvey has called forth a noble plea for experimental investigation which it is to be hoped will be read by every physician. I refer to the article entitled William Harvey which Huxley has published in the Fortnightly Review, and which was reprinted in the March supplement of The Popular Science Monthly. Harvey's claims to the gratitude of mankind, and particularly to that of our profession, are admirably displayed, and the lesson which his life teaches is so forcibly demonstrated that it acquires almost a new value. It lessens our pride to think that our manner of studying medicine contains so little of this experimental method which Huxley thinks has done so much for the world; to think that it even furnishes so little of the culture necessary to fit us for the exercise of this method in the long years of waiting that must elapse between graduation and a full practice. Still it may be wholesome for us to reflect that our "practical" standard is a very low one, and that, without dreaming or sentimentalizing over an ideal, the world offers us models of a much better application of these experimental methods than any which our wisdom has led us to imitate. An immediate corollary of this thought is that new buildings and longer courses of study are not of so much importance to us as a thorough and radical overturning of the system that crowds our students with lectures to such an extent that they have no time for the essentials of medical education. More than this, the article itself is a practical illustration of the value of medical history. Times change, but human nature is much the same as Shakespeare found it; Harveys and Riolans, Asselis and Helmonts still exist, and history can only show us to what extent these different types of men may bless or curse our science. It seems that there were, as there now are, three types of men, as far as their manner of working is concerned. In Harvey we see the patient seeker for truth, - patient in the consciousness of working for the future; in Riolan we can see the busy, selfish worker, with just enough of "distant vision" to be concerned for his epitaph; while in the hosts of the "practical" men of their day we see the throngs who are busied with the present. History alone can teach us to honor and imitate the one class while it enables us to assign a just value to the others ; more than this, it alone may give us the clews that we need in shaping our policy in educational matters, - a policy the results of which will reach far into the future. History may also serve the ends of justice in adjusting the confusion and mistakes of one period in the clearer light which time sheds upon events that have long since happened. It is this latter function of history to which, incited by the ref- 
erence to Spigelius in the article by Huxley, I would devote a few lines concerning Julius Casserius Placentinus, a name that has received too little honor in the annals of medicine. Chance has left his fame in a great measure to a department of medical history that has been relatively but slightly cultivated. I refer to the bibliographical and artistic branches. This has happened as follows: When Fabricius ab Aquapendente, the professor of anatomy and surgery in Padua, vacated his chair in the university he was succeeded by his pupil and most illustrious rival, Casserius, who had long been engaged in the attempt to produce an anatomy worthy of his age. To accomplish this purpose Casserius had engaged the services of Fialetti, a pupil of Cremonini and Tintoretto, as draughtsman, and Franciscus Vallesius, one of the best engravers of the age, to furnish plates for the work. Unfortunately, Casserius died before the text was ready, and Spigelius, who succeeded to the chair, was soon by the same fate prevented from completing his labors, yet not until he had enriched medical literature by several important contributions. Spigelius made Daniel Bucretius (Rindfleisch) his literary executor, and particularly enjoined upon him the publication of his anatomy in ten books. During the time that Bucretius was employed in preparing these labors of Spigelius for publication he came into possession of the plates of Casserius, and in the same year that he published the anatomy of Spigelius (1627) he published them with explanatory notes, but without text. The two works were, however, so arranged that they complemented each other, and they were soon united. ${ }^{1}$

This union was rather injurious to the reputation of Casserius, for the plates and their history were nearly forgotten, and although the name of Casserius was generally mentioned in connection with them, they were commonly regarded as parts of the works of Spigelius. There can be no doubt that they represent the second great epoch in the history of modern anatomy, counting the work of Vesalius as marking the beginning of its history. Sprengel cites as an instance of their value that they represent the so-called aqueduct of Sylvius, and in the seventh plate (page 90, first edition) this structure is shown and thus plainly described in the explanatory text: "Q. Q. Nates divisi, ut ductus, qui sub ipsis latebat, conspiceretur. $R$. Ductus posterior tertii ventriculi in quartum tendens, apertus."

The same irreverence that was attached to merely pictured facts may have actuated Johannes Browne when, in 1683, he published his anatomy with thirty or more plates copied from those of Casserius.

1 I have not seen a copy of one of the 1627 editions so united; I state the fact upon the authority of Möhsen (Verzeichniss einer Sammlung von Bildnissen grössentheil berühmter Aertze. Berlin. 1771.) My own editions are : first, the first edition of 1627, with the title-page which distinguishes it; second, the edition of Casserius and Spigelius, published by Vander Linden, 1645, which contains Harvey's account of the discovery of the circulalation and Asselli's description of the lymphatics; third, a German edition of the plates of Casserius published at Frankfort in 1656 (small quarto). 
But it was not my intention to do more than call attention to the fact that when we speak of the works of Spigelius we almost always include the plates of Casserius without thinking that the author of the plates probably deserves more honor than the worthy author of the text. Justice requires that these facts, upon which medical history is usually silent, should be remembered, and that we should not permit the name and merits of one of the greatest anatomists to be buried in the works of an author who, judging from his life, would have been the first to have protested against the injustice.

\section{RECENT PROGRESS IN PHYSIOLOGY.}

BY H. P. BOWDITCH, M. D.

\section{MUSCULAR CONTRACTION.}

VoLUNTARY muscular contractions have generally been regarded by physiologists as resulting from the fusion of a rapid series of muscular twitches, ${ }^{2}$ such as are caused by a single induction shock applied to a motor nerve or to a muscle. A strong argument in favor of this view in the minds of the earlier physiologists was the fact that they were unable to produce artificially a persistent tetanus resembling a voluntary contraction in any way except by a series of irritations following each other in rapid succession. In accordance with this theory the trembling of the muscles resulting from age, disease, or exhaustion was considered to be due to the impulses from the central nervous system following each other with a rapidity insufficient to produce a complete fusion of the separate muscular twitches. ${ }^{3}$

Du Bois-Reymond's ${ }^{4}$ investigations into the electrical phenomena of nerves and muscles lent force to this theory; for he was able to show that a "negative variation" of the normal muscle current is a necessary concomitant of muscular activity, that it is sufficiently intense to act as an irritant to a nerve placed upon the surface of the muscle, and that a nerve thus irritated produces in the muscle belonging to it a condition of contraction corresponding to that of the primary muscle. Thus, if the primary muscle is caused to twitch by a single induction shock applied to its nerve, the second muscle will also twitch in consequence of the irritation of its nerve by the "negative variation" of the first muscle; and if a rapid series of induction shocks causes the first muscle to contract tetanically, the secondary contraction will also be tetanic in

1 Concluded from page 598.

2 This word is used as the English equivalent of the German zuckung or the French secousse.

3 See Ed. Weber in Wagner's Handwörterbuch der Physiologie, iii. Bd., ii. Abth., s. 12.

4 Untersuchungen über thierische Electricität. 